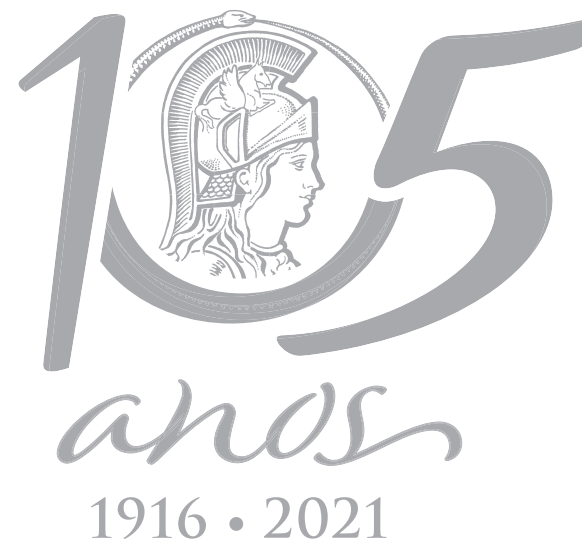

$1916 \cdot 2021$

\title{
Range extensions of three marine shrimps (Caridea: Alpheidae, Palaemonidae) on the Brazilian coast
}

\author{
LUCIANE A.A. FERREIRA, CECILI B. MENDES \& PAULO P.G. PACHELLE
}

\begin{abstract}
Three caridean shrimps have their distribution range extended on the Brazilian coast. Alpheus carlae Anker, 2012 (Alpheidae), previously reported from Ceará to São Paulo, and Typton fapespae Almeida, Anker \& Mantelatto, 2014 (Palaemonidae), previously known only from Rio de Janeiro and São Paulo, are both now reported from Santa Catarina, the new southernmost record of these species in the Atlantic Ocean. Athanas nitescens (Leach, 1813) (Alpheidae), an invasive species from the eastern Atlantic first reported from São Paulo in 2012 based on a single male, is now confirmed to have established populations in Brazil with the finding of ovigerous females on the coast of Rio de Janeiro. Illustrations for all three species are provided based on the new material.
\end{abstract}

Key words: Biodiversity, Crustacea, Decapoda, southwestern Atlantic, intertidal.

\section{INTRODUCTION}

The infraorder Caridea Dana, 1852 comprises the second most speciose infraorder of decapod crustaceans with over 3400 described species (De Grave et al. 2009, De Grave \& Fransen 2011, Herrera-Barquín et al. 2018). Carideans have great ecological relevance due to their role in the food chain and presence in many different aquatic habitats, from pelagic to benthic species within marine, brackish and freshwater environments (De Grave \& Anker 2008).

In Brazil, there have been many attempts to summarize the caridean diversity (RamosPorto \& Coelho 1990, 1991, 1998, Christoffersen 1998, Melo 2003, Coelho et al. 2006, Ferreira et al. 2010, Vieira et al. 2012, Soledade \& Almeida 2013). However, due to the Brazilian's wide and habitat diverse coast, the distributional range of many shrimp species is still far from being completely understood. As a result, many recent studies have been published dealing with new records, filling distributional gaps for various species and thus providing valuable information for future marine biodiversity assessments (e.g., Cardoso 2009, Pachelle et al. 2011, 2012, 2015, 2016, Almeida et al. 2012a, b, 2013, 2015, 2018, Anker et al. 2014, 2016, Giraldes \& Freire 2015 and more).

In a series of collections made in two southeastern states of Brazil in 2017, three species of caridean shrimps were obtained and later found to represent the new southernmost record for these species on the Brazilian coast and the southwestern Atlantic Ocean.

\section{MATERIALS AND METHODS}

The specimens were collected under rocks during low tide in three localities in the states of Rio de Janeiro and Santa Catarina. After collection, the 
specimens were anesthetized in a solution of clove oil and seawater, then photographed prior preservation in $70 \%$ ethanol. In laboratory, the individuals were sexed, measured and drawn with the aid of a stereomicroscope equipped with a camera lucida. Carapace length ( $c l$, in $\mathrm{mm}$ ) was used as standard size parameter, measured from the post-orbital angle along the dorsal mid-line to the posterior margin of the carapace; specifically for Alpheus carlae Anker, 2012, because the rostrum is very short and the ocular hood obscures the post-orbital angle, cl was measured from the tip of the rostrum to the posterior margin of the carapace. All material is deposited in the carcinological collection of the Museu de Zoologia, Universidade de São Paulo (MZUSP), São Paulo, Brazil.

\section{RESULTS AND DISCUSSION}

Systematics

Order Decapoda Latreille, 1802

Infraorder Caridea Dana, 1852

Family Alpheidae Rafinesque, 1815

\section{Alpheus carlae Anker, 2012}

Alpheus carlae Anker, 2012: 61, figs. 41-48, 64H, 65H, 66H, 67G, 68B - Santos et al. 2012: 150, fig. 3C - Soledade and Almeida 2013: 97, fig. 4D Almeida et al. 2013: 1398 - Soledade et al. 2015: 57, fig. 3C - Almeida et al. 2018: 336, fig. 1C.

\section{Material examined}

Brazil, Santa Catarina, Florianópolis, Santo Antônio beach, 27030'17.8"S 48ㅇ3'23.1"W, under rock, C. Mendes \& P. Pachelle colls., 23 June 2017: 1 male (cl 9.6 mm), MZUSP 39069.

\section{Distribution}

Western Atlantic: USA (Florida), Puerto Rico, Jamaica, Belize, Panama, Venezuela, French Guyana, Brazil (Ceará, Paraíba, Pernambuco,
Alagoas, Bahia, Rio de Janeiro, São Paulo and Santa Catarina) (Anker 2012, Soledade \& Almeida 2013, Almeida et al. 2018, present study).

\section{Remarks}

Alpheus carlae (Figure 1) belongs to the large and taxonomically challenging $A$. armillatus $\mathrm{H}$. Milne-Edwards, 1837 species complex (Anker 2012). Nonetheless, A. carlae can be readily recognized in life by its diagnostic color pattern, especially in the major and minor chelae covered with several bluish blotches and the pleon with three paired black spots, each pair distributed along the second, third and fourth somites (Figure 1). Previously known from Florida to São Paulo (see full record in Anker 2012, Soledade \& Almeida 2013), the specimen from Santa Catarina represents the new southernmost record of the species in the western Atlantic, extending its distribution in at least 2 degrees of south latitude from Cananéia, São Paulo (Anker 2012) to Florianópolis, Santa Catarina (present study).

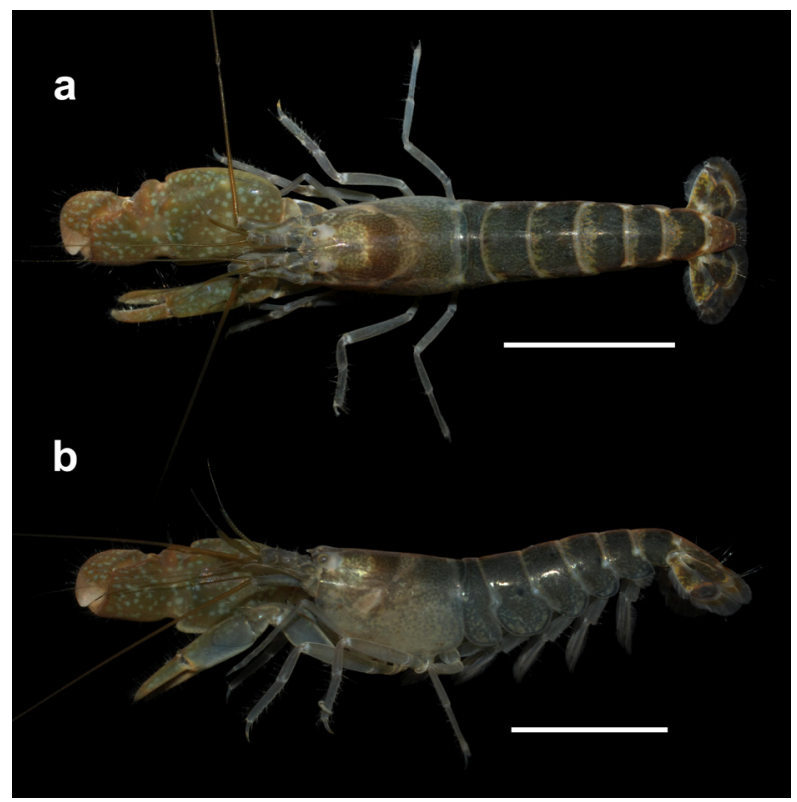

Figure 1. Alpheus carlae Anker, 2012, male, cl 9.6 mm (MZUSP 39069), in dorsal (a) and lateral (b) views. Scale bars: $10 \mathrm{~mm}$. 
Athanas nitescens (Leach, 1813)

Palaemon nitescens Leach, 1813: 401.

Athanas nitescens (Leach, 1813) - Holthuis and Gottlieb, 1958: 27, figs. 2-3 - Almeida et al. 2012b: 560, fig. 2a-k - Almeida et al. 2018: 343, fig. 2B.

\section{Material examined}

Brazil, Rio de Janeiro, Paraty, Pontal beach, 23이'50.8"S 44ㅇ42'43.7"W, under rocks, C. Mendes \& P. Pachelle colls., 09 May 2017: 1 female (cl 2.9 $\mathrm{mm}$ ), 2 ovigerous females (cl 2.9, $3.6 \mathrm{~mm}$ ), MZUSP 39070.

\section{Distribution}

Eastern Atlantic: southwestern Norway to Republic of the Congo, including the Mediterranean. Western Atlantic: Brazil (Rio de Janeiro and São Paulo) (Holthuis \& Gottlieb 1958, Crosnier 1971, Almeida et al. 2012b; present study).

\section{Remarks}

Athanas nitescens, (Figure 2) a species with extensive distribution in the eastern Atlantic, was first reported in the western Atlantic based on a single male collected in the state of São Paulo, Brazil (Almeida et al. 2012b). According to Almeida et al. (2012b), if A. nitescens had established populations in the area, the populations from São Paulo could then act as source for dispersion to nearby states, following the same pattern as Athanas dimorphus Ortmann, 1894, another invasive species in Brazil (Pachelle et al. 2011, Almeida et al. 2012b). In fact, the discovery of ovigerous females in Rio de Janeiro confirms that the species is spreading to other states. Among the characters listed in Almeida et al. (2012b: table I), A. nitescens can be easily separated from its invasive congener in that the first chelipeds carried extended (vs. carried folded in A. dimorphus) and the frontal

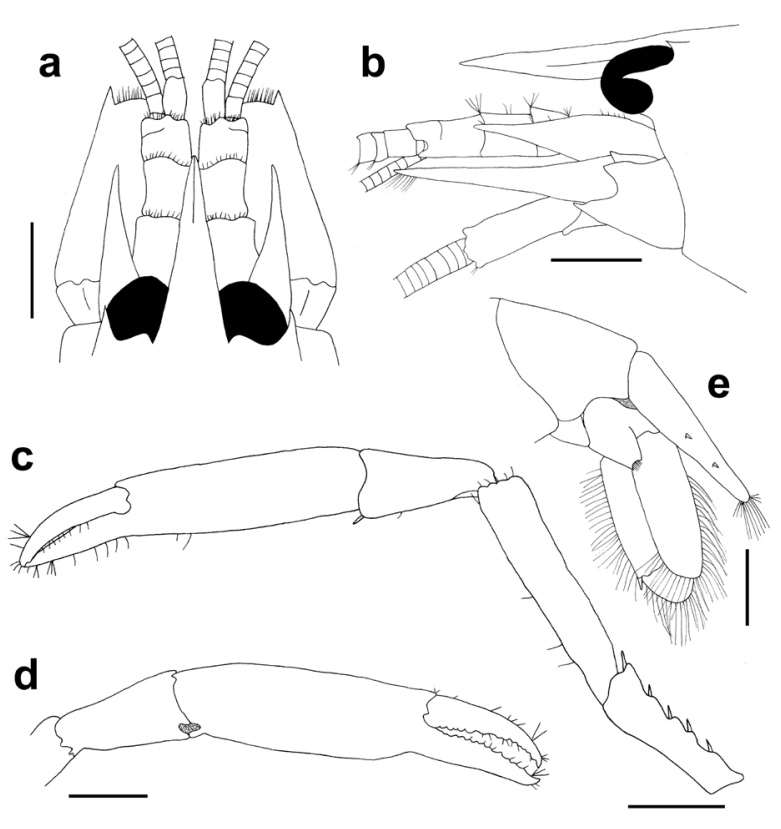

Figure 2. Athanas nitescens (Leach, 1813), ovigerous female, cl 2.9 mm (MZUSP 39070). a. Frontal margin and cephalic appendages, dorsal view; b. Same, lateral view; c. Left P1, lateral view; d. Same, chela and carpus, mesial view; E. Sixth abdominal segment, left uropod and telson, lateral view. Scale bars: $0.5 \mathrm{~mm}$.

margin of carapace bearing a supra-orbital tooth (vs. without supra-orbital tooth in $A$. dimorphus) (Figure 2b, d; Almeida et al. 2012b: fig. 1b, g-i). Athanas nitescens is known for displaying a number of polymorphic characters, including proportions of the first chelipeds and antennular peduncles, shape of the rostrum and armature of fifth abdominal pleura in the populations across the eastern Atlantic (cf. Holthuis \& Gottlieb 1958). Although A. nitescens may be a species complex (Anker 2001, Anker \& Ahyong 2007), our specimens present the typical form for the species, resembling the individual figured in Almeida et al. (2012b). Whether the Rio de Janeiro population originated from São Paulo or constitutes a new invasion remains to be confirmed in future genetic analysis.

Palaemonidae Rafinesque, 1815

Typton fapespae Almeida, Anker and Mantelatto, 2014 
Typton gnathophylloides - Nalesso et al. 1995: 96 - Duarte and Nalesso, 1996: 143 - Amaral et al. 2010: 249 [not T. gnathophylloides Holthuis, 1951]

Typton fapespae Almeida, Anker and Mantelatto, 2014: 111, figs. 1-5 - Pachelle et al. 2015: 319.

\section{Material examined}

Brazil, Santa Catarina, Florianópolis, Ribeirão da Ilha, rocky shore, $27^{\circ} 43^{\prime} 02.4^{\prime \prime} \mathrm{S} 48^{\circ} 33^{\prime} 51.2^{\prime \prime} \mathrm{W}$, under rock, inside orange sponge, C. Mendes \& P. Pachelle colls., 24 June 2017: 1 ovigerous female (cl $1.9 \mathrm{~mm}$ ), MZUSP 39072; 1 male (cl $2.0 \mathrm{~mm}$ ), MZUSP 39073; 1 ovigerous female (cl $1.8 \mathrm{~mm}$ ), MZUSP 39074; 1 male (cl 2.1 mm), MZUSP 39075.

\section{Distribution}

Western Atlantic: Brazil (Rio de Janeiro, São Paulo and Santa Catarina) (Almeida et al. 2014, Pachelle et al. 2015; present study).

\section{Remarks}

Typton fapespae (Figures 3, 4) was recently described and is so far a species endemic to Brazil (Almeida et al. 2014). Among the other Brazilian species of Typton Costa, 1844, T. fapespae is readily recognized by the strong median tooth on the distal margin of the sixth pleonal somite (Figure 4e). After its discovery in São Paulo, the species was reported one year later from Rio de Janeiro (Pachelle et al. 2015), and is now also known from Santa Catarina (present study). Thus, Florianópolis is the new southernmost record of the species in Brazil and the western Atlantic, extending its distribution in at least 2 degrees of south latitude.

\section{Acknowledgments}

We wish to thank two anonymous reviewers for providing valuable comments that greatly improved the originally submitted manuscript. Marcos Tavares (MZUSP) is acknowledged for providing laboratorial space during

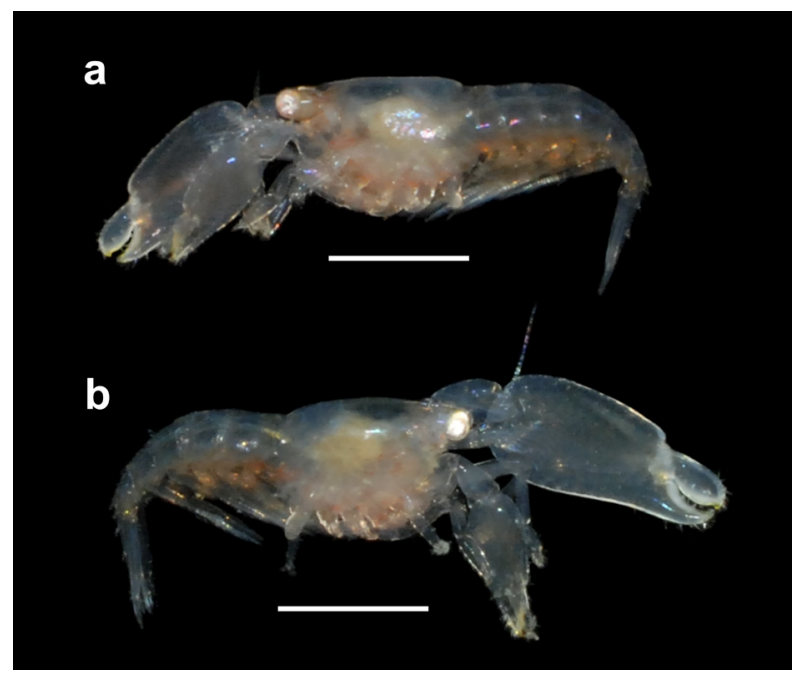

Figure 3. Typton fapespae Almeida, Anker \& Mantelatto, 2014, ovigerous females, (a) cl $1.9 \mathrm{~mm}$, (b) cl $1.8 \mathrm{~mm}$, lateral view. Scale bars: $2 \mathrm{~mm}$.

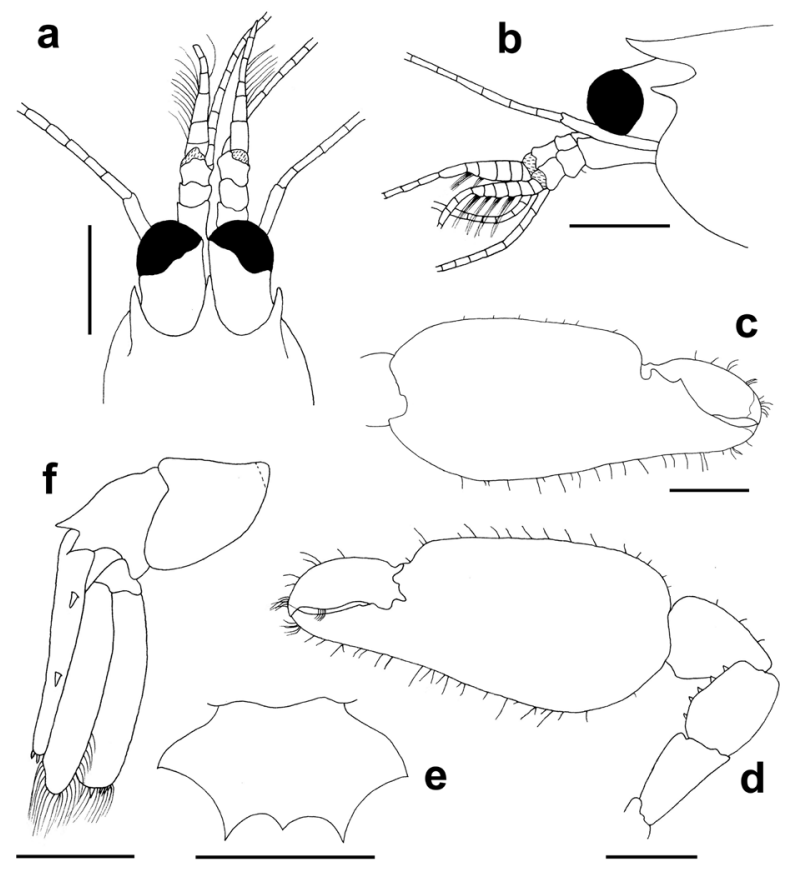

Figure 4. Typton fapespae Almeida, Anker \& Mantelatto, 2014, ovigerous female, cl $1.8 \mathrm{~mm}$ (MZUSP 39074). a. Frontal margin and cephalic appendages, dorsal view; b. Same, lateral view; c. Left major P2, chela, mesial view; d. Same, entire cheliped, lateral view; e. Sixth abdominal segment, dorsal view; f. Sixth abdominal segment, right uropod and telson, lateral view. Scale bars: $0.5 \mathrm{~mm}$. 
the execution of the study and access to the collection under his care. This study was partially funded by Fundação de Amparo à Pesquisa do Estado de São Paulo (FAPESP) in the form of a PhD scholarship allowed to CBM (process number 2016/20005-5).

\section{REFERENCES}

ALMEIDA AO, ANKER A \& MANTELATTO FL. 2014. A new snapping species of the shrimp genus Typton Costa, 1844 (Decapoda: Palaemonidae) from the coast of São Paulo, southeastern Brazil. Zootaxa 3835(1): 110-120.

ALMEIDA AO, BOEHS G, ARAÚJO-SILVA CL \& BEZERRA LEA. 2012a. Shallow-water caridean shrimps from southern Bahia, Brazil, including the first record of Synalpheus ul (Ríos \& Duffy, 2007) (Alpheidae) in the southwestern Atlantic Ocean. Zootaxa 3347: 1-35.

ALMEIDA AO, COSTA-SOUZA AC, CUNHA AM, SANTOS PS, OLIVEIRA MV \& SOLEDADE GO. 2013. Estuarine caridean shrimps (Crustacea: Decapoda) from Ilhéus, Bahia, Brazil: Updated checklist and a key for their identification. Check List 9(6): 1396-1405.

ALMEIDA AO, COSTA-SOUZA AC, SOLEDADE GO \& SANTOS PS. 2015. Conquering new territories in the "new world": the alien shrimp Athanas dimorphus Ortmann, 1894 (Decapoda: Alpheidae) on the coast of Pernambuco, northeastern Brazil. Nauplius 23: 120-124.

ALMEIDA AO, SIMÕES SM, COSTA RC \& MANTELATTO FL. 2012b. Alien shrimps in evidence: new records of the genus Athanas Leach, 1814 on the coast of São Paulo, southern Brazil (Caridea: Alpheidae). Helgol Mar Res 66: 557-565.

ALMEIDA AO, TEROSSI M, BURANELLI RC, CASTILHO AL, COSTA RC, ZARA FJ \& MANTELATTO FL. 2018. Checklist of decapods (Crustacea) from the coast of São Paulo State (Brazil) supported by integrative molecular and morphological data: II. Infraorder Caridea: family Alpheidae. Zootaxa 4450(3): 331-358.

AMARAL ACZ, MIGOTTO AE, TURRA A \& SCHAEFFER-NOVELLI Y. 2010. Araçá: biodiversidade, impactos e ameaças. Biota Neotrop 10: 219-264.

ANKER A. 2001. Two new species of snapping shrimps from the Indo-Pacific, with remarks on colour patterns and sibling species in Alpheidae (Crustacea: Caridea). Raffles B Zool 49(1): 57-72.

ANKER A. 2012. Revision of the western Atlantic members of the Alpheus armillatus H. Milne Edwards, 1837 species complex (Decapoda, Alpheidae), with description of seven new species. Zootaxa 3386: 1-109.

ANKER A \& AHYONG ST. 2007. Description of two species in the alpheid shrimp genus Athanas Leach, 1814, with remarks on A. amazone Holthuis, 1951 (Decapoda, Caridea). Zootaxa 1563: 17-30.

ANKER A, PACHELLE PPG \& TAVARES M. 2014. Two new species and two new records of deep-water caridean shrimps from Brazil (Decapoda: Pandalidae, Palaemonidae, Crangonidae). Zootaxa 3815: 263-278.

ANKER A, TAVARES M \& MENDONÇA JB. 2016. Alpheid shrimps (Decapoda: Caridea) of the Trindade \& Martin Vaz Archipelago, off Brazil, with new records, description of a new species of synalpheus and remarks on zoogeographical patterns in the oceanic islands of the tropical southern Atlantic. Zootaxa 4138: 1-58.

CARDOSO IA. 2009. First record of Parapontophilus longirostris Komai, 2008 (Caridea, Crangonidae) on Brazilian waters. Nauplius 17: 29-35.

CHRISTOFFERSEN ML. 1998. Malacostraca. Eucarida. Caridea, Crangonoidea and Alpheoidea (except Glyphocrangonidae and Crangonidae). In: Young PS (Ed). Catalogue of Crustacea of Brazil, Rio de Janeiro, Museu Nacional, p. 351-372.

COELHO PA, ALMEIDA AO, SOUZA-FILHO JF, BEZERRA LEA \& GIRALDES BW. 2006. Diversity and distribution of the marine and estuarine shrimps (Dendrobranchiata, Stenopodidea and Caridea) from North and Northeast Brazil. Zootaxa 1221: 41-62.

CROSNIER A. 1971. Sur quelques Crustacés Décapodes ouest-africains nouveaux ou rarement signalés. Bull Mus Natl Hist Nat Series 3 Zool 9: 569-595.

DE GRAVE S ET AL. 2009. A classification of living and fossil genera of decapod crustaceans. Raffles B Zool 21: 1-109.

DE GRAVE S \& ANKER A. 2008. Global diversity of shrimps (Crustacea: Decapoda: Caridea) in freshwater. Hydrobiologia 595: 287-293.

DE GRAVE S \& FRANSEN CHJM. 2011. Carideorum catalogus: the recent species of the dendrobranchiate, stenopodidean, procarididean and caridean shrimps (Crustacea: Decapoda). Zool Meded 89: 195-589.

DUARTE LFL \& NALESSO RC. 1996. The sponge Zygomycale parishii (Bowerbank) and its endobiotic fauna. Estuar Coast Shelf Sci 42: 139-151.

FERREIRA RS, VIEIRA RRR \& D'INCAO F. 2010. The marine and estuarine shrimps of the Palaemoninae (Crustacea: Decapoda: Caridea) from Brazil. Zootaxa 2606: 1-24.

GIRALDES BW \& FREIREAS. 2015. Extending the southern range of four shrimps (Crustacea: Decapoda: Stenopodidae, Hippolytidae and Alpheidae) in southwestern Atlantic (270-S) and confirming the presence of Mediterranean Stenopus spinosus Risso, 1827 in Brazil. Zootaxa 3972: 419-431.

HERRERA-BARQUIIN H, LEIJA-TRISTÁN A \& FAVELA-LARA S. 2018. Updated checklist of estuarine caridean shrimps 
(Decapoda: Caridea) from the southern region of Laguna Madre, Tamaulipas, Mexico, with new records and a key for taxonomic identification. Check List 14(2): 479-494.

HOLTHUIS LB \& GOTTLIEB E. 1958. An annotated list of the decapod Crustacea of the Mediterranean coast of Israel, with an appendix listing the Decapoda of the Eastern Mediterranean. B Res Counc Israel 7B(1-2): 1-126.

MELO GAS. 2003. Manual de identificação dos Crustacea Decapoda de água doce do Brasil, São Paulo: Edições Loyola, 429 p.

NALESSO RC, DUARTE LFL, PIEROZZI I JR \& ENUMO EF. 1995. Tube epifauna of the polychaete Phyllochaetopterus socialis Claparède. Estuar Coast Shelf Sci 41: 91-100.

PACHELLE PPG, ANKER A, MENDES CB \& BEZERRA LEA. 2016. Decapod crustaceans from the state of Ceará, northeastern Brazil: an updated checklist of marine and estuarine species, with 23 new records. Zootaxa 4131(1): $1-63$.

PACHELLE PPG, ANKER A \& TAVARES M. 2015. New and additional records of the sponge shrimp genus Typton Costa, 1844 (Decapoda: Palaemonidae) from the Brazilian coast. Pap Avulsos Zool 55(22): 317-322.

PACHELLE PPG, MENDES CB \& ANKER A. 2011. The Indo-West Pacific alpheid shrimp Athanas dimorphus Ortmann, 1894: first record for Brazil and the Western Atlantic. Nauplius 19(1): 89-96.

PACHELLE PPG, PAIVA SV, OLIVEIRA FILHO RR \& ANKER A. 2012. The ascidian-associated shrimp Ascidonia miserabilis (Caridea: Palaemonidae): first record for Brazil and additional records for the Caribbean Sea. Mar Biodivers Rec 5(e83): 1-5.

RAMOS-PORTO M \& COELHO PA. 1990. Sinopse dos crustáceos decápodos brasileiros (família Palaemonidae). An Soc Nord Zool 3: 93-111.

RAMOS-PORTO M \& COELHO PA. 1991. Sinopse dos crustáceos decápodos brasileiros (família Hippolytidae). Trab Oceanogr da Univ Fed PE 22: 181-189.

RAMOS-PORTO M \& COELHO PA. 1998. Malacostraca. Eucarida. Caridea (Alpheoidea excluded). In: Young PS (Ed). Catalogue of Crustacea of Brazil, Rio de Janeiro, Museu Nacional, p. 325-350.

SANTOS PS, SOLEDADE GO \& ALMEIDA AO. 2012. Decapod crustaceans on dead coral from reef areas on the coast of Bahia, Brazil. Nauplius 20(2): 145-169.

SOLEDADE GO \& ALMEIDA AO. 2013. Snapping shrimps of the genus Alpheus Fabricius, 1798 from Brazil (Caridea: Alpheidae): updated checklist and key for identification. Nauplius 21(1): 89-122.

SOLEDADE GO, FONSECA MS \& ALMEIDA AO. 2015. Shallowwater stenopodidean and caridean shrimps from
Abrolhos Archipelago, Brazil: new records and updated checklist. Zootaxa 3905(1): 52-68.

VIEIRA RRR, FERREIRA RS \& D'INCAO F. 2012. Pontoniinae (Crustacea: Decapoda: Caridea) from Brazil with taxonomic key. Zootaxa 3149: 1-38.

\section{How to cite}

FERREIRA LAA, MENDES CB \& PACHELLE PPG. 2021. Range extensions of three marine shrimps (Caridea: Alpheidae, Palaemonidae) on the Brazilian coast. An Acad Bras Cienc 93: e20190634. DOI 10.1590/00013765202120190634.

Manuscript received on May 30, 2019;

accepted for publication on October 28, 2019

\section{LUCIANE A.A. FERREIRA ${ }^{1}$}

https://orcid.org/0000-0003-1683-9962

\section{CECILI B. MENDES ${ }^{2}$}

https://orcid.org/0000-0002-9041-1270

\section{PAULO P.G. PACHELLE 3}

https://orcid.org/0000-0003-0093-9352

${ }^{1}$ Museu de Zoologia, Universidade de São Paulo, Av. Nazareth, 481, 04263-000 São Paulo, SP, Brazil

${ }^{2}$ Laboratório de Diversidade Genômica, Departamento de Genética e Biologia Evolutiva, Instituto de Biociências, Universidade de São Paulo, Rua do Matão, 277, 05508-090 São Paulo, SP, Brazil

${ }^{3}$ Museu de Zoologia, Universidade de São Paulo, Laboratório de Carcinologia, Av. Nazaré, 481, 04263-000 São Paulo, SP, Brazil

Correspondence to: Luciane Augusto de Azevedo Ferreira

E-mail: lucianeaaf@gmail.com

\section{Author contribution}

Luciane A.A. Ferreira: Wrote the main text and did the drawings. Cecili B. Mendes: Collected and photographed the specimens, revised and formatted the text. Paulo P.G. Pachelle Collected, photographed and identified the specimens, revised and formatted the text.

\section{(cc) BY}

